Is there a too-big-to-fail discount in excess returns on German banks' stocks? Thomas Nitschka
SNB Working Papers
$8 / 2015$ 


\section{Legal Issues}

\section{DISCLAIMER}

The views expressed in this paper are those of the author(s) and do not necessarily represent those of the Swiss National Bank. Working Papers describe research in progress. Their aim is to elicit comments and to further debate.

\section{COPYRIGHT@}

The Swiss National Bank (SNB) respects all third-party rights, in particular rights relating to works protected by copyright (information or data, wordings and depictions, to the extent that these are of an individual character).

SNB publications containing a reference to a copyright (C) Swiss National Bank/SNB, Zurich/year, or similar) may, under copyright law, only be used (reproduced, used via the internet, etc.) for non-commercial purposes and provided that the source is mentioned. Their use for commercial purposes is only permitted with the prior express consent of the SNB.

General information and data published without reference to a copyright may be used without mentioning the source. To the extent that the information and data clearly derive from outside sources, the users of such information and data are obliged to respect any existing copyrights and to obtain the right of use from the relevant outside source themselves.

\section{LIMITATION OF LIABILITY}

The SNB accepts no responsibility for any information it provides. Under no circumstances will it accept any liability for losses or damage which may result from the use of such information. This limitation of liability applies, in particular, to the topicality, accuracy, validity and availability of the information.

ISSN 1660-7716 (printed version)

ISSN 1660-7724 (online version)

(C) 2015 by Swiss National Bank, Börsenstrasse 15,

P.O. Box, $\mathrm{CH}-8022$ Zurich 


\title{
Is there a too-big-to-fail discount in excess returns on German banks' stocks?
}

\author{
Thomas Nitschka ${ }^{1}$ \\ Swiss National Bank
}

22 June 2015

\begin{abstract}
This paper shows that standard multifactor asset pricing models provide an adequate description of excess returns on stock indexes of German industrial sectors. The only exception is the banking sector index. It offers lower monthly excess returns than suggested by exposures to risk factors in the sample period from 1973 to 2014. This evidence is robust to various changes in the specification of the empirical model. Rolling time window regressions highlight that this finding has been most pronounced since the peak of the global financial crisis in 2008/2009 when the government guarantee for big, systemically important German banks became explicit.
\end{abstract}

JEL: G10, G21

Keywords: banking sector, multifactor models, risk factors, risk premia

\footnotetext{
${ }^{1}$ Mailing address: Thomas Nitschka, Monetary Policy Analysis, Swiss National Bank, Börsenstrasse 15, P.O. Box, CH-8022 Zurich;

Phone: +41-(0)44-6313628; Fax : +41 (0)446313175 ; E-mail: thomas.nitschka@snb.ch

This paper benefitted from comments and suggestions by Katrin Assenmacher, an anonymous referee of the SNB working paper series and participants in the SNB Brown Bag Seminar. Any errors and omissions are my own. The views expressed in this paper are mine and do not necessarily reflect the stance of the Swiss National Bank.
} 


\section{Introduction}

Financial institutions that are considered to be 'too big' or 'too systemically important' to fail enjoy lower funding costs than suggested by measures of their credit and default risks. This stylized fact is the consequence of implicit or explicit government guarantees (Rime, 2005; Ueda and Weder di Mauro, 2013). Creditors assume that governments will support big, systemically important financial institutions if they come under existential threat.

In addition, the evidence presented in Gandhi and Lustig (2015) suggests that the too-big-tofail status of big banks is not only visible in comparatively low funding costs but also reflected in returns on their stocks. There is a size premium in returns on stocks of U.S. commercial banks. Large banks' stocks offer lower returns than suggested by their exposures to standard risk factors. There is no such evidence for stocks of small commercial banks. Gandhi and Lustig (2015) rationalize this bank size effect in a disaster risk model. Investors accept low average returns on big banks' stocks because they provide a hedge against an economic disaster. The hedging value of big banks' stocks is related to government subsidies. Small banks do not enjoy such a subsidy.

Against this background, this paper assesses if investors in stocks of big German banks have been willing to accept lower average excess returns than suggested by the sensitivity of German banks' stock returns to measures of systematic risk over the sample period from February 1973 to June 2014.

The motivation for the focus on Germany in this context is threefold. First, the government guarantee for systemically important German financial institutions became explicit at the peak of the global financial crisis in 2008/2009. Various financial institutions received government help, e.g. in the form of direct capital injections or credit guarantees by the German government or federal states (Deutsche Bundesbank, 2009). Second, strong financial integration among euro area countries (e.g. Spiegel, 2009; Nitschka, 2010) and the dominant role of Germany in the euro area (Balgar, 2014; Minton Beddoes, 2013) suggest that risks in 
the German financial system could have an impact on the state of the whole euro area economy. Improving our understanding of the determinants of risk premia on stocks of German banks is hence vital. Third, the strong increase of German banks' exposures to other euro area economies since the introduction of the euro (Hale and Obstfeld, 2014) makes the German banking system sensitive to risks that materialize in other euro area economies. For example, the sovereign debt crisis in the euro area since 2010 is an episode during which a government guarantee for German banks could have been particularly valuable to investors. This hypothesis is also suggested by evidence of a significant link between European banks' stock returns and sovereign risks provided by Bessler and Kurmann (2014).

The empirical assessment presented in this paper takes the form of time series regressions of excess returns on bank and other German industries' stock indexes on excess returns on risk factor mimicking portfolios. Since both dependent and explanatory variables are excess returns, the asset pricing model's performance is not only reflected in the measure of fit but also in the estimate of the constant in the regression. If the model is an adequate description of the data, then the constant should be indistinguishable from zero (Black et al., 1972). If the regression coefficient of the constant in the time series regressions is different from zero, then there is evidence of 'abnormal' or significant 'risk-adjusted' returns.

The regression estimates reveal that sensitivity to excess returns on standard risk factor mimicking portfolios (Fama and French, 1993; Carhart, 1997) provides an adequate description of average excess returns on stock indexes of almost all German industrial sectors. The banking sector index is the exception. The average excess return on the banking sector index is lower than suggested by the exposures to standard measures of systematic risk. The risk-adjusted excess return on the German bank stock index is negative. This evidence is in line with Gandhi and Lustig (2015) because the German bank stock index is dominated by few, big banks. It is hence natural to interpret this finding as reflection of a too-big-to-fail 
discount for returns on German banks' stocks. This finding is robust to adding various other measures of systematic risk as explanatory variables to the benchmark asset pricing model.

Finally, this paper uses rolling time window regressions to evaluate if the evidence of negative risk-adjusted returns is driven by particular episodes of the sample period. If the negative risk-adjusted return on the German bank stock index reflects a government guarantee, we should expect it to be particularly pronounced since the financial market turmoil around the Lehman collapse at the end of 2008. At that time the government guarantee for systemically important banks became explicit.

Indeed the rolling window regressions show that the evidence of negative risk-adjusted returns on the German bank sector index is to most extent driven by the years since the Lehman collapse in 2008 and the subsequent euro area sovereign debt crisis. This finding suggests that stock market investors took the explicit government guarantee since the peak of the global financial crisis into account when evaluating the risk-return trade-off of German banks' stocks.

The remainder of the paper is structured as follows. Section 2 provides the details of the data. Section 3 gives the methodological background of the empirical framework. Section 4 presents the results of the asset pricing tests. Finally, section 5 concludes.

\section{Data and descriptive statistics}

The sample covers the period from February 1973 to June 2014. The data is measured at the monthly frequency and denominated in Deutschmark/euro. I use a one-month German money market rate/Euribor to obtain asset returns in excess of the risk-free rate. The money market rate data is from Datastream. All returns are expressed in percent per month.

\subsection{Dependent variables: Stock indexes of German industrial sectors}

To measure risk premia associated with the state of the German economy I use a selection of stock indexes of German industrial sectors that are compiled by Datastream. These indexes are total return indexes, i.e. dividends are taken into account by assuming they are reinvested 
in the index. The selected indexes cover the following sectors: Banks, insurances, basic materials, industrials, consumer goods, health care, consumer services, telecom and utilities. The data is available via Datastream.

Table 1 provides the mean excess returns, i.e. the return on the respective total return index in excess of the one-month money market rate, in percent per month and the associated tstatistics of the mean excess return. The t-statistic is the mean excess return divided by its sample standard error.

In general, the excess returns on the German industry stock indexes are so volatile that their means are not more than two standard errors away from zero over the sample period. The banking sector index stands out, however, because it is the only index that delivered negative, but statistically insignificant, average excess returns. By contrast, the other financial services sector - insurers - and the basic materials sector provided the highest average excess returns of about $0.4 \%$ per month.

\section{[about here Table 1]}

\subsection{Explanatory variables: Risk factor mimicking portfolios}

\subsubsection{Factors of the benchmark model}

The benchmark asset pricing model of this paper employs the risk factor mimicking portfolios proposed by Fama and French (1993) and Carhart (1997), henceforth simply referred to as risk factors. I use the German versions of these factors (stocks from all segments of the German stock market and taking into account tax credits) compiled and described in detail by Brückner et al. (2015). The treatment of tax credit adjustments is not particularly important in the context of this paper. But the use of all segments of the German stock market, including microcap stocks, takes recent insights from Fama and French (2012) into account. Fama and French (2012) show that microcap stocks provide important information about systematic 
risks. The data on various German versions of the Fama and French (1993) and Carhart (1997) risk factors is publicly available on Richard Stehle's website 2 .

The first risk factor is the excess return on a broad stock market index $\left(r_{t}^{e, M}\right)$ to empirically approximate the excess return on the market portfolio (the portfolio comprising all risky assets) in the capital asset pricing model (CAPM) of Sharpe (1964) and Lintner (1965). The second and the third risk factors proposed by Fama and French (1993) are supposed to take into account patterns in average stock returns that are not well captured by exposure to the market return alone. These "anomalies" include extraordinarily high returns on diversified portfolios of small firms' stocks (small in terms of market capitalization) as compared with portfolios of big firms' stocks. The return on the zero net investment strategy of going long in portfolios of small and shorting portfolios of large firms' stocks $\left(S M B_{t}\right)$ summarizes this pattern. In addition, Fama and French (1993) advocate the return on the zero net investment strategy of going long in portfolios of stocks with high book-to-market equity ratios and shorting portfolios of stocks with low book-to-market equity ratios $\left(H M L_{t}\right)$ as additional risk factor to capture the fact that high (low) book-to-market equity stocks offer higher (lower) returns than expected from their sensitivity to the market return.

Carhart (1997) proposes an empirical model of mutual fund performance that incorporates a summary measure of momentum in stock returns (Jegadeesh and Titman, 1993). Portfolios of stocks based on these stocks' past short-term performance (momentum) deliver excess returns that are not only different from zero but are also not captured by the Fama and French (1993) model. Therefore, Carhart (1997) proposes to use the return difference between portfolios of stocks with a history of positive returns and stocks with a history of low returns $\left(W M L_{t}\right)$ as additional risk factor.

\footnotetext{
${ }^{2}$ https://www.wiwi.hu-berlin.de/professuren/bwl/bb/data
} 
The four factors motivated above, the Carhart (1997) model, constitute the benchmark empirical asset pricing model of this study. As robustness checks, I employ other factors described in the subsequence.

\subsubsection{Other risk factors}

Fama and French (1993) propose the excess return on a portfolio of government bonds as common risk factor. This factor could be particularly interesting in the context of assessing bank stocks. Flannery and James (1984) show that returns on US commercial bank stocks react sensitively to interest rate risks because of the maturity mismatch on banks' asset and liability side. Moreover, this factor could be interpreted as measuring the risk of the sovereign that potentially bails out the banks. I compiled this factor $\left(g o v_{t}\right)$ for Germany by subtracting the one-month money market rate from the monthly return on the German government bond index, REX. The total return version of REX, i.e. taking coupon payments into account, is obtained via Datastream.

Moreover, I employ the excess return on the MSCI Europe index that excludes the German stock market as a proxy of risks at the European level in the robustness checks. This (total return) stock index is obtained via Datastream.

Finally, I use a new stock market risk factor proposed by Frazzini and Pedersen (2014) in the robustness checks. This factor is calculated as the return difference between stock portfolios with low past exposure to the market excess return and portfolios with past high exposure to the market return $\left(B A B_{t}\right)$. Since this portfolio return is long the low exposure ("beta") and short the stocks with high exposure to the market return, Frazzini and Pedersen (2014) call this factor the "Betting against Beta" factor $\left(B A B_{t}\right)$. Consistent with their theoretical model, Frazzini and Pedersen (2014) show that returns on $B A B$ are low in times of high funding liquidity risks and vice versa. It is hence a natural, potential determinant of banks' risks because the materialization of funding liquidity risks of financial institutions help to explain the unfolding of the global financial crisis in 2008/2009 (Brunnermeier, 2009). The $B A B$ data 
is publicly available on the AQR capital management website ${ }^{3}$. The sample period for the German version of the $B A B$ factor starts in December 1988.

\subsubsection{Descriptive statistics of risk factors}

Table 2 presents the descriptive statistics (mean return in \% per month and the t-statistic of the mean return) of the explanatory variables. All of the risk factors exhibit positive excess returns with the exception of $S M B$. Brückner et al. (2015) stress that the negative average excess return on $S M B$ is a pervasive observation across almost all sets of German Fama and French (1993) risk factor datasets. Over the full sample period, the WML factor provided the highest average return of $0.95 \%$ per month. There is a strong momentum effect in the German stock market. The German and the European (excluding Germany) stock market indexes provided comparable average excess returns of about $0.4 \%$ per month.

\section{[about here Table 2]}

\section{Methodological background}

The methodological background for the subsequent empirical analysis is the basic insight that expected discounted returns on any asset should be constant. In the case of excess returns, i.e. returns in excess of the risk-free rate or return differences between asset portfolios, the expected excess return on any asset $i, r_{t}^{i, e}$, discounted by the stochastic discount factor, $m_{t}$, should be zero (Cochrane, 2005), i.e.

$$
0=E_{t}\left(r_{t+1}^{i, e} m_{t+1}\right)
$$

I assume a linear form of the stochastic discount factor. Normalizing the constant term in the linear specification to unity, i.e. $m_{t+1}=1-f_{t+1}^{\prime} b$, taking unconditional expectations and rearranging gives

$$
E\left(r_{t}^{i, e}\right)=\operatorname{cov}\left(r_{t}^{i, e} f_{t}\right) b
$$

\footnotetext{
${ }^{3}$ https://www.aqr.com/library/data-sets
} 
in which $f_{t}$ denotes a $k \times 1$ vector of risk factors and $b$ denotes the corresponding vector of loadings on the factors.

I use the beta representation of equation (2) in the empirical analysis. The beta representation allows to express equation (2) in terms of (multiple) regression coefficients and is obtained by multiplying the right-hand side of equation (2) with $\Sigma_{f}^{-1} \Sigma_{f}$, such that

$$
E\left(r_{t}^{i, e}\right)=\operatorname{cov}\left(r_{t}^{i, e} f_{t}\right) \Sigma_{f}^{-1} \Sigma_{f} b
$$

in which $\Sigma_{f}$ is the variance/covariance matrix of the risk factors and the following definitions $\operatorname{cov}\left(r_{t}^{i, e} f_{t}\right) \Sigma_{f}^{-1}=\beta^{i}$ and $\Sigma_{f} b=\lambda$ apply. Then equation (4) can be rewritten as

$$
E\left(r_{t}^{i, e}\right)=\beta^{i} \lambda
$$

highlighting that expected excess returns on asset $i$ are a function of asset $i$ 's sensitivities $\left(\beta^{i}\right)$ to the risk factors and the risk prices of these factors $(\lambda)$ which are the same for all assets (Cochrane, 2005).

The empirical part of this paper uses excess returns on stock indexes of industrial sectors as test assets. Furthermore, it employs varieties of empirical asset pricing models in which the risk factors $(f)$ are approximated by excess returns on risk factor mimicking portfolios. Hence, we can directly apply the beta representation in equation (4) to the empirical approximations of the risk factors too. In a regression of the excess return on the risk factor mimicking portfolio of risk factor A on itself, the regression coefficient is unity, such that $E\left(r_{t}^{A, e}\right)=\lambda^{A}$. Therefore, the pricing equation (4) can be translated into a time series regression because the risk prices should be approximately equal to the unconditional average excess returns on the risk factor mimicking portfolios. The regression then takes the following form

$$
r_{t}^{i, e}=a^{i}+\beta_{A}^{i} r_{t}^{e, A}+\beta_{B}^{i} r_{t}^{e, B}+\ldots+\varepsilon_{t}^{i}, t=1, \ldots T
$$

where $\mathrm{A}$ and $\mathrm{B}$ denote different risk factors and superscript $e$ an excess return. 
As all factors and the dependent variables are approximated by excess returns (returns in excess of the risk-free rate or return differences between portfolios), the estimates of the constant $(a)$ in the regression (5) should be zero if the empirical model adequately describes the dependent excess returns (Black et al. ,1972). This is a direct implication of the pricing equation (4). Hence, if the estimate of the constant is different from zero, then there are "abnormal" or significant "risk-adjusted" returns, i.e. returns that are unrelated to the risk factor proxies.

\section{$4 \quad$ Empirical results}

\subsection{Empirical framework and results}

The baseline empirical results are obtained from regressions of excess returns on stock indexes of German industrial sectors, $r_{t}^{e, i}$, on the risk factors proposed by Fama and French (1993) and Carhart (1997) described in section 2.2.1. These baseline regressions take the following form:

$$
r_{t}^{e, i}=a^{i}+m^{i} r_{t}^{e, M}+s^{i} S M B_{t}+h^{i} H M L_{t}+w^{i} W M L_{t}+\varepsilon_{t}^{i}, t=1, \ldots T
$$

Table 3 summarizes the regression results for stock indexes of nine different German industrial sectors. Even though the focus of this study is the German banking sector, running these regressions helps to evaluate if the empirical model is an adequate description of the German industrial sector indexes in general.

The first line of table 3 gives the results from the regression in equation (6) when the excess return on the German bank sector index is the dependent variable. The estimate of the constant is $-0.4 \%$ per month and statistically different from zero at conventional significance levels. Since publicly listed German banks are typically big and systemically important ${ }^{4}$, this evidence supports the hypothesis of Gandhi and Lustig (2015). Investors take the prospect of a potential government bailout of these banks in times of stress into account and accept a risk

\footnotetext{
${ }^{4}$ Total assets of the big, publicly listed banks tend to be as high as total assets of German savings banks and credit cooperatives or Landesbanken and regional institutions (Deutsche Bundesbank, 2014). Hence, the big banks are only a subset of potentially systemically important German banks.
} 
premium (excess return) that is lower than suggested by the exposure to measures of systematic risk.

Is this finding really special to banks or a general feature of stocks from the financial sector? The second line of table 3 shows that the excess returns on an index of insurance companies do not exhibit significant risk-adjusted returns. The constant in the time series regression is indistinguishable from zero even though the empirical model captures about $70 \%$ of the variation in the excess returns of the insurance companies' stock index. This is comparable with the model fit for the excess return on the banking sector index. Moreover, the exposures to the market return of 1.2 and to the SMB factor (roughly 0.25 ) are about the same for the insurance and banking sector stock index. In addition, the banking sector index is significantly related to the HML factor which could be interpreted as measure of distress risk (Kapadia, 2011). But in contrast to the insurance sector index the estimate of the constant in the regression of the excess return on the banking sector index is different from zero.

Three other observations from table 3 are noteworthy. First, in the regressions for the other industrial sectors we do not observe a significant estimate of the constant. The excess return on the German banking sector index is the only incidence of a negative and statistically significant risk-adjusted excess return. Second, excess returns on the banking and insurance sector index exhibit the highest exposure to the German market return of all of the industrial sectors under study. Third, despite evidence of a strong momentum effect (high average return on the WML factor) in the German stock market, its role in determining average industrial sector returns is negligible. The regression estimates of the WML coefficient in table 3 are in no case different from zero at the $95 \%$ confidence level.

In sum, the Fama and French (1993) and Carhart (1997) model appears to be an adequate description of excess returns on stock portfolios of German industrial sectors. However, the banking sector index is an exception. It offers a negative risk-adjusted excess return which could be interpreted as a too-big-to-fail discount. Investors accept lower returns on big banks' 
stocks because the implicit or explicit government guarantee for these banks adds hedging value (Gandhi and Lustig, 2015).

\section{[about here Table 3]}

If this latter interpretation of the negative risk-adjusted excess return on the German bank stock index is correct, we should observe variation of this too-big-to-fail discount over time. Ueda and Weder di Mauro (2013) highlight that the funding cost subsidy enjoyed by systemically important financial institutions increased from about 60 basis points until the end of 2007 to roughly 80 basis points after the global financial crisis in 2008/2009 made the government guarantee for these financial institutions explicit.

In order to evaluate if a similar reasoning applies to the negative risk-adjusted return on the German banking sector index, I perform the regression in equation (6) over a rolling time window of 120 months to obtain a time series of the constant, i.e. the risk-adjusted return.

Figure 1 depicts the time series of the constant's point estimates as solid, blue line and the point estimate $+/$ - two standard errors of the point estimate as a gauge of the uncertainty surrounding this estimate in dotted, red lines. The dashed, black line indicates a value of zero. The first data point is the estimate of the constant from the regression of the German bank stock excess return on the risk factors from February 1973 to February 1983. The second data point gives the corresponding estimate from March 1973 to March 1983 and so forth.

The time series pattern of the risk-adjusted return on the stock index of the German banking sector suggests that it was slightly negative (between $-0.5 \%$ to $-0.2 \%$ per month) in the latter part of the 1980s around the global stock market turmoil in 1987. It has moved around zero for most of the sample period, i.e. from the early 1990s until the peak of the global financial crisis in 2008. In the aftermath of the Lehman collapse, when the government guarantee for big and systemically important banks became explicit, the risk-adjusted return on the German bank stock index dropped to values around $-1.5 \%$ per month and stayed there until the end of the sample period in June 2014. 
These observations are consistent with the findings of Ueda and Weder di Mauro (2013) of an increase of the funding cost subsidy of systemically important financial institutions after government guarantees became explicit in 2008. It is also consistent with the interpretation of the negative risk adjusted returns on big banks' stocks as reflection of the government bailout guarantee (Gandhi and Lustig, 2015).

\section{[about here Figure 1]}

\subsection{Robustness Checks}

The baseline results of a significant, negative risk-adjusted return on the German bank stock index has so far been interpreted as evidence of a government guarantee for big, systemically important German banks. However, it could also reflect a misspecified empirical model in the sense that the benchmark model misses a measure of systematic risks that is particularly important for banks. Therefore, this section provides results from regressions of excess returns on the stock index of the German banking sector on the risk factors from the baseline regression and additional risk factors that could have an impact on German banks' stock returns.

This section starts with including the excess return on a German government bond index (gov) as additional factor in the asset pricing model. The motivation to include this factor is twofold. First, Flannery and James (1984) show that stocks of US commercial banks react sensitively to measures of interest rate risks, such as changes in government bond prices/yields, because of the typical maturity mismatch between the asset and liability side of banks' balance sheets. Second, the excess return on a government bond portfolio is a measure of the risks attributed to the government that potentially bails out banks. If the sovereign's risk is high, then the probability of a bailout should fall and hence the value of the government subsidy for big, systemically important banks.

This robustness regression takes the following form 


$$
\begin{aligned}
& r_{t}^{e, i}=a^{i}+m^{i} r_{t}^{e, M}+s^{i} S M B_{t}+h^{i} H M L_{t}+w^{i} W M L_{t} \\
& +g^{i} g_{0} v_{t}+\varepsilon_{t}^{i}, t=1, \ldots T
\end{aligned}
$$

The first line in panel A of table 4 displays the results for this regression. The excess return on the German banking sector index is only insignificantly related to the excess return of the German government bond index. Most importantly, the evidence of negative risk-adjusted returns on the bank stock index remains unaltered.

As an additional factor I consider the excess return on a European stock market index that excludes Germany $\left(r_{t}^{\text {MEurExGer }}\right)$ in the regression setup to control for international, here European, risks. The motivation for this robustness check comes from Griffin (2002) who shows that the Fama and French (1993) factors rather capture country-specific than international risks. In this robustness check the regression is given by

$$
\begin{aligned}
& r_{t}^{e, i}=a^{i}+m^{i} r_{t}^{e, M}+s^{i} S M B_{t}+h^{i} H M L_{t}+w^{i} W M L_{t} \\
& +g^{i} \text { gov }_{t}+e^{i} r_{t}^{M E u r E x G e r}+\varepsilon_{t}^{i}, t=1, \ldots T
\end{aligned}
$$

The second line in panel A of table 4 presents the corresponding estimates. Again we observe a negative risk-adjusted return on the stock index of the German banking sector. The German banking sector index return is not significantly linked to the European stock market index that excludes German stocks.

Finally, displayed in panel B of table 4, I additionally control for the "Betting against Beta" $(B A B)$ factor of Frazzini and Pedersen (2014) who highlight that this factor is linked to changes in funding liquidity risks and hence a potential determinant of banks' stock returns. The regression specification is given by equation (9).

$$
\begin{aligned}
& r_{t}^{e, i}=a^{i}+m^{i} r_{t}^{e, M}+s^{i} S M B_{t}+h^{i} H M L_{t}+w^{i} W M L_{t} \\
& +g^{i} \text { gov }_{t}+e^{i} r_{t}^{M E u r E x G e r}+b^{i} B A B_{t}+\varepsilon_{t}^{i}, t=1, \ldots T
\end{aligned}
$$

The $B A B$ factor is only available since December 1988 . The shorter sample period explains some changes in the regression coefficients of the other factors. For example, during this (sub)sample period we observe a significant link between excess returns on German banks' 
stocks and the excess returns on the government bond index as well as the WML factor. In addition, the $B A B$ factor is significantly related to the excess return on the stock index of the German banking sector. However, there is still evidence of a negative risk-adjusted return on the German bank stock index.

\section{Conclusions}

This paper has documented that the average excess return on a stock index of the German banking sector is significantly lower than suggested by its exposure to standard risk factors over the sample period from February 1973 to June 2014. On average, the risk-adjusted return on the German banking sector index is negative. The observation of a negative risk-adjusted excess return on the German banks' stock index is robust to variations in the multifactor asset pricing framework. Banks' stocks are special because the standard multifactor models provide an adequate description of excess returns on stock indexes of other German industrial sectors. Rolling window regressions reveal that this observation is to most extent driven by the period after the peak of the global financial crisis in 2008/2009 when the government guarantee for systemically important financial institutions became explicit. In addition, the stock index of German banks under study is dominated by big banks. Hence, a natural interpretation of the negative risk-adjusted excess return on the German banking sector index is a too-big-to-fail discount on big banks' stocks. 


\section{References}

Balgar, C., 2014. What Lies Ahead of Germany's Leadership Role in Europe. Global Economic Observer 2, 65-75.

Bessler, W., Kurmann, P., 2014. Bank risk factors and changing risk exposures: Capital market evidence before and during the financial crisis. Journal of Financial Stability 13, 151166.

Black, F., Jensen, M.C.,Scholes, M.S., 1972. The Capital Asset Pricing Model: Some Empirical Tests. In: Studies In The Theory Of Capital Markets, Ed.: Michael C. Jensen, Praeger Publishers Inc., http://ssrn.com/abstract=908569.

Brückner, R., Lehman, P., Schmidt, M.H., Stehle, R., 2015. Fama/French Factors for Germany: Which Set Is Best? Working paper http://ssrn.com/abstract=2390063.

Brunnermeier, M.K., 2009. Deciphering the Liquidity and Credit Crunch 2007-2008. Journal of Economic Perspectives 23, 77-100.

Carhart, M.M., 1997. On Mutual Fund Performance. Journal of Finance 52, 57-82.

Cochrane, J.H., 2005. Asset Pricing, $2^{\text {nd }}$ edition, Princeton University Press, Princeton.

Deutsche Bundesbank, 2009. Financial Stability Review.

Deutsche Bundesbank, 2014. Financial Stability Review.

Fama, E.F., French, K.R., 1993. Common risk factors in the returns on stocks and bonds. Journal of Financial Economics 33, 3-56.

Fama, E.F., French, K.R., 2012. Size, value and momentum in international stock returns. Journal of Financial Economics 105, 457-472.

Flannery, M.J., James, C.M., 1984. The Effect of Interest Rate Changes on the Common Stock Returns of Financial Institutions. Journal of Finance 39, 1141-1153.

Frazzini, A., Pedersen, L.H., 2014. Betting against beta. Journal of Financial Economics 111, $1-25$.

Gandhi, P., Lustig, H., 2015. Size Anomalies in U.S. Bank Stock Returns. Journal of Finance $70,733-768$.

Griffin, J.M., 2002. Are the Fama and French Factors Global or Country Specific? Review of Financial Studies, 15, 783-803.

Hale, G.B., Obstfeld, M., 2014. The Euro and the Geography of International Debt Flows. Federal Reserve Bank of San Francisco Working Paper 2014-10.

Jegadeesh, N., Titman, S., 1993. Returns to buying winners and selling losers: Implications for stock market efficiency. Journal of Finance 48, 65-91. 
Kapadia, N., 2011. Tracking down distress risk. Journal of Financial Economics 102, $167-$ 182.

Lintner, J., 1965, The valuation of risk assets and the selection of risky investments in stock portfolios and capital budgets. Review of Economics and Statistics 47, 13-37.

Minton Beddoes, Z., 2013. Special Report: Germany - Europe's reluctant hegemon. The Economist, June $15^{\text {th }} 2013$.

Newey, W.K., West, K.D., 1987. A Simple, Positive Semidefinite, Heteroskedasticity and Autocorrelation Consistent Covariance Matrix. Econometrica 55, 703-708.

Nitschka, T., 2010. Cashflow news, the value premium and an asset pricing view on European stock market integration. Journal of International Money and Finance 29, 1406-1423.

Rime, B., 2005. Do 'Too Big to Fail' Expectations Boost Large Banks' Issuer Ratings? Mimeo Swiss National Bank.

Sharpe, W.F., 1964, Capital asset prices: A theory of market equilibrium under conditions of risk, Journal of Finance 19, 425-442.

Spiegel, M.M., 2009. Monetary and Financial Integration in the EMU: Push or Pull? Review of International Economics 17, 751-776.

Ueda, K., Weder di Mauro, B., 2013. Quantifying structural subsidy values for systemically important financial institutions. Journal of Banking and Finance 37, 3830-3842. 


\section{Tables}

Table1: Mean excess returns on German sector stock indexes

\begin{tabular}{ccc}
\hline Sector & Mean (\% p.m.) & t-stat (mean) \\
Banks & -0.07 & -0.20 \\
Insurers & 0.42 & 1.34 \\
Basic Materials & 0.46 & 1.82 \\
Industrials & 0.32 & 1.20 \\
Consumer Goods & 0.23 & 0.70 \\
Health Care & 0.33 & 1.70 \\
Consumer Services & 0.11 & 0.40 \\
Telecom & 0.04 & 0.11 \\
Utilities & 0.29 & 1.56 \\
\hline
\end{tabular}

Notes: This table displays mean returns in excess of the one-month Euribor on stock indexes of various German industrial sectors expressed in \% per month. The t-statistic of the mean is defined as mean excess return divided by its sample standard error. The indexes take dividend payments into account (total return indexes) and are compiled by Datastream. The sample period runs from February 1973 to June 2014. 
Table 2: Mean excess returns on explanatory variables

Panel A: Fama and French (1993) and Carhart (1997) factors

\begin{tabular}{ccc}
\hline Factor & Mean (\% p.m.) & t-stat (mean) \\
$r_{t}^{e, M}$ & 0.40 & 1.76 \\
$S M B_{t}$ & -0.41 & -2.83 \\
$H M L_{t}$ & 0.51 & 4.05 \\
$W M L_{t}$ & 0.95 & 4.50 \\
\hline gov & Other factors & 3.17 \\
$r_{t}^{M E u r E x G e r}$ & 0.15 & 2.17 \\
BAB & 0.45 & 3.15 \\
\hline
\end{tabular}

Notes: This table presents the means (in \% per month) of excess returns on factor mimicking portfolios that are used as explanatory variables in the asset pricing tests. The t-statistic of the mean is defined as mean excess return divided by its sample standard error. The sample period runs from February 1973 to June 2014 for all factors except $B A B$. This sample period for $B A B$ is December 1988 to June 2014.

The factors are the excess return on a broad German stock market index $\left(r_{t}^{e, M}\right)$, the return difference between diversified portfolios of small firms' and big firms' stocks (SMB), the return difference between diversified portfolios of firms with high and low book-to-market equity ratio (HML) and the return difference between portfolios of stocks with a history of positive returns and stocks with a history of low returns (WML). Brückner et al. (2015) compiled this dataset which is available on Richard Stehle's website.

The other factors are: The return on the German government bond index, REX, in excess of a one-month money market rate (Gov) obtained from Datastream. The excess return on the MSCI Europe excluding Germany total return stock index $\left(r_{t}^{\text {MEurExGer }}\right)$ obtained via Datastream and the return difference between portfolios of stocks with low and high past exposures to the market return $\left(B A B_{t}\right)$ proposed and made publicly available by Frazzini and Pedersen (2014) on the AQR capital management website. 
Table 3: Risk factor exposures of excess returns on German sectoral stock indexes

\begin{tabular}{|c|c|c|c|c|c|c|c|}
\hline sector & $a$ & $m$ & $s$ & $h$ & $w$ & 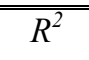 & $\overline{D D W}$ \\
\hline \multirow[t]{2}{*}{ Banks } & -0.41 & 1.21 & 0.25 & 0.19 & -0.15 & 0.68 & 1.89 \\
\hline & $(-2.15)$ & (22.78) & (3.44) & (2.59) & $(-1.69)$ & & \\
\hline \multirow[t]{2}{*}{ Insurers } & 0.05 & 1.20 & 0.22 & -0.03 & 0.00 & 0.69 & 2.00 \\
\hline & $(0.23)$ & (17.48) & (3.08) & $(-0.24)$ & $(0.01)$ & & \\
\hline \multirow[t]{2}{*}{ Basic Materials } & -0.08 & 0.86 & -0.12 & 0.37 & -0.05 & 0.75 & 2.16 \\
\hline & $(-0.70)$ & (23.33) & $(-2.29)$ & (5.09) & $(-1.24)$ & & \\
\hline \multirow[t]{2}{*}{ Industrials } & -0.09 & 1.00 & -0.01 & 0.16 & -0.09 & 0.83 & 2.08 \\
\hline & $(-0.95)$ & (28.00) & $(-0.25)$ & (2.94) & $(-1.75)$ & & \\
\hline \multirow[t]{2}{*}{ Consumer Goods } & -0.28 & 1.02 & -0.01 & 0.21 & -0.01 & 0.53 & 2.17 \\
\hline & $(-1.25)$ & (14.61) & $(-0.06)$ & $(1.45)$ & $(-0.06)$ & & \\
\hline \multirow[t]{2}{*}{ Health Care } & 0.00 & 0.68 & 0.23 & 0.14 & 0.07 & 0.52 & 1.92 \\
\hline & $(0.02)$ & (14.35) & (3.88) & $(1.40)$ & $(1.58)$ & & \\
\hline \multirow[t]{2}{*}{ Consumer Services } & $-0-25$ & 0.98 & 0.20 & 0.19 & -0.05 & 0.64 & 2.12 \\
\hline & $(-1.63)$ & (19.44) & (2.92) & (3.22) & $(-1.01)$ & & \\
\hline \multirow[t]{2}{*}{ Telecom } & -0.26 & 0.92 & -0.16 & -0.29 & 0.02 & 0.42 & 1.95 \\
\hline & $(-0.91)$ & (11.85) & $(-1.30)$ & $(-1.72)$ & $(0.16)$ & & \\
\hline \multirow[t]{2}{*}{ Utilities } & 0.07 & 0.48 & 0.12 & 0.25 & -0.05 & 0.33 & 1.89 \\
\hline & $(0.42)$ & (8.52) & $(1.80)$ & (3.79) & $(-1.03)$ & & \\
\hline
\end{tabular}

Notes: This table presents the estimates from a regression of excess returns on German sectoral stock indexes on a constant $(a)$, three risk factors proposed by Fama and French (1993): the market excess return $(m)$, SMB $(s)$, HML $(h)$ and one factor proposed by Carhart (1997): WML (w). Newey-West (Newey and West, 1987) corrected t-statistics appear below the estimates in parenthesis. Bold faces highlight estimates that are significant at the 95\% confidence level. The $R^{2}$ statistic is adjusted for the number of regressors. The Durbin-Watson statistic $(D W)$ tests for autocorrelation of the residuals. A value around two indicates no autocorrelation of the regression residuals. The sample period runs from February 1973 to June 2014. 
Table 4: Risk factor exposures of excess returns

on German bank stock index: Alternative risk factors

\begin{tabular}{|c|c|c|c|c|c|c|c|c|}
\hline \multicolumn{9}{|c|}{ Panel A: Sample period February 1973 to June 2014} \\
\hline$a$ & $m$ & $s$ & $h$ & $w$ & $g$ & $e$ & $b$ & $R^{2}$ \\
\hline-0.43 & 1.21 & 0.25 & 0.18 & -0.15 & 0.19 & & & 0.68 \\
\hline$(-2.32)$ & (22.17) & (3.46) & (2.52) & $(-1.72)$ & $(1.17)$ & & & \\
\hline-0.45 & 1.14 & 0.24 & 0.17 & -0.15 & 0.19 & 0.09 & & 0.68 \\
\hline$(-2.36)$ & (21.99) & (3.50) & (2.48) & $(-1.72)$ & (1.15) & $(1.27)$ & & \\
\hline \multicolumn{9}{|c|}{ Panel B: Sample period December 1988 to June 2014} \\
\hline$a$ & $m$ & $s$ & $h$ & $w$ & $g$ & $e$ & $b$ & $R^{2}$ \\
\hline-0.70 & 1.00 & 0.28 & 0.21 & -0.22 & 0.20 & -0.00 & 0.43 & 0.68 \\
\hline$(-2.36)$ & (11.57) & (3.58) & (2.54) & $(-2.28)$ & $(2.05)$ & $(-0.02)$ & (3.64) & \\
\hline
\end{tabular}

Notes: This table presents the estimates from a regression of excess returns on the German bank stock index on a constant $(a)$, three risk factors proposed by Fama and French (1993): the market excess return $(m)$, SMB $(s)$, HML $(h)$ and one factor proposed by Carhart (1997): WML $(w)$. Additional risk factors are the excess return on a government bond index $(g)$, the excess return on a European stock market index excluding Germany $(e)$ and the "Betting against Beta" (b) risk factor. Newey-West (Newey and West, 1987) corrected t-statistics appear below the estimates in parenthesis. Bold faces highlight estimates that are significant at the $95 \%$ confidence level. The $R^{2}$ statistic is adjusted for the number of regressors. The sample period runs from February 1973 to June 2014 for the regressions including the government bond excess return and the excess return on the European market portfolio excluding Germany. The sample starts in December 1988 when the "Betting against Beta" factor $(\mathrm{BAB})$ is included as additional regressor due to the limited availability of this factor. 


\section{Figures}

Figure 1: Time series of risk adjusted excess return on the stock index of the German banking sector (in \% per month)

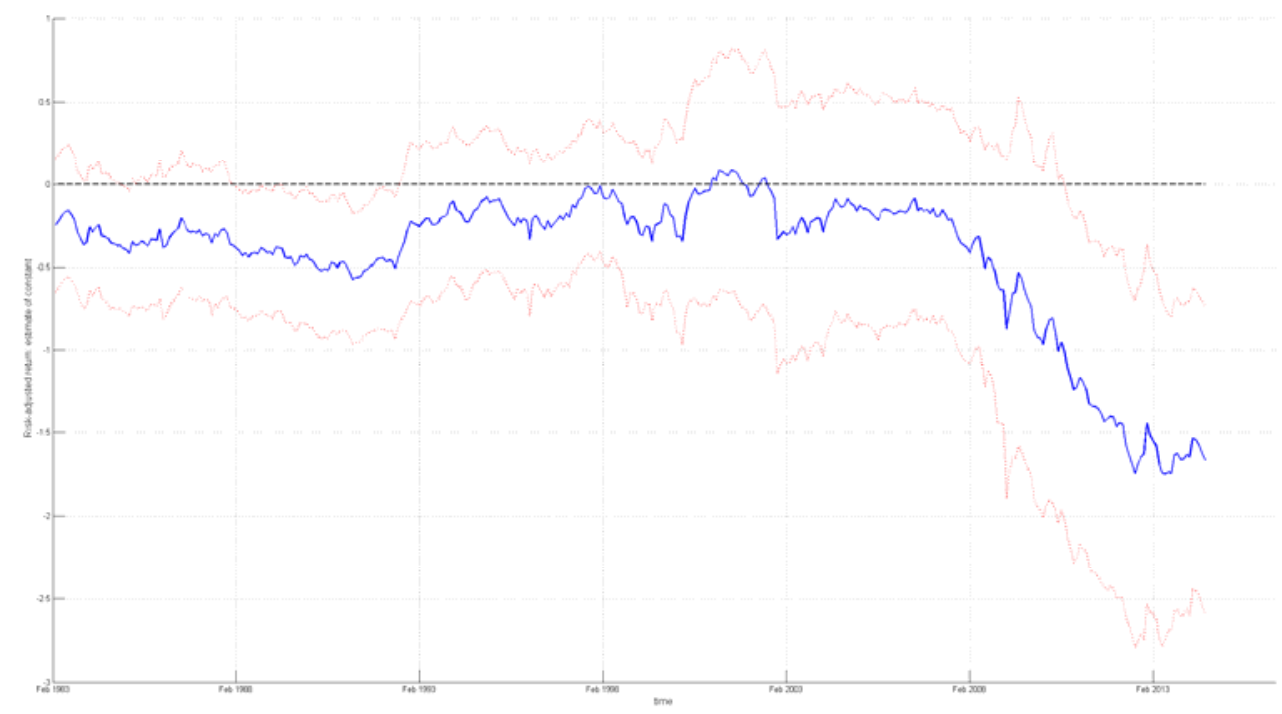

Notes: The time series of the risk-adjusted excess return on the German banking sector index is obtained from 120-month rolling window regressions over the sample period from February 1973 to June 2014. The blue solid line depicts the point estimates of the risk adjusted return and the red, dotted lines are the point estimates +/- two standard errors to indicate the uncertainty surrounding the estimate. The dashed black line indicates a risk-adjusted return level of zero. 


\section{Recent SNB Working Papers}

2015-8 Thomas Nitschka: Is there a too-big-to-fail discount in excess returns on German banks' stocks?

2015-7 Alin Marius Andries, Andreas M. Fischer and Pinar Yeşin: The impact of international swap lines on stock returns of banks in emerging markets.

2015-6 Jens H.E. Christensen an Signe Krogstrup: Transmission of Quantitative Easing: The Role of Central Bank Reserves

2015-5 Petra Gerlach-Kristen and Seán Lyons: Mortgage arrears in Europe: The impact of monetary and macroprudential policies.

2015-4 Reto Foellmi, Sandra Hanslin and Andreas Kohler: A dynamic North-South model of demand-induced product cycles.

2015-3 Katarina Juselius and Katrin Assenmacher: Real exchange rate persistence: The case of the Swiss franc-US dollar rate.

2015-2 Lucas Marc Fuhrer, Basil Guggenheim and Silvio Schumacher: Re-use of collateral in the repo market.

2015-1 Pinar Yeşin: Capital flow waves to and from Switzerland before and after the financial crisis.

2014-13 Thomas Nitschka: Have investors been looking for exposure to specific countries since the global financial crisis? - Insights from the Swiss franc bond market.

2014-12 Christian Grisse and Thomas Nitschka: Exchange rate returns and external adjustment: evidence from Switzerland.
2014-11 Rina Rosenblatt-Wisch and Rolf Scheufele: Quantification and characteristics of household inflation expectations in Switzerland.

2014-10 Gregor Bäurle and Daniel Kaufmann: Exchange rate and price dynamics in a small open economy - the role of the zero lower bound and monetary policy regimes.

2014-9 Matthias Gubler and Christoph Sax: Skill-Biased Technological Change and the Real Exchange Rate.

2014-8 Tommaso Mancini Griffoli, Christoph Meyer Jean-Marc Natal and Attilio Zanetti: Determinants of the Swiss Franc Real Exchange Rate.

2014-7 Konrad Adler and Christian Grisse: Real exchange rates and fundamentals: robustness across alternative model specifications.

2014-6 Matthias Gubler: Carry Trade Activities: A Multivariate Threshold Model Analysis.

2014-5 Raphael A. Auer and Aaron Mehrotra: Trade linkages and the globalisation of inflation in Asia and the Pacific.

2014-4 Cyril Monnet and Thomas Nellen: The Collateral Costs of Clearing.

2014-3 Filippo Brutti and Philip Sauré: Repatriation of Debt in the Euro Crisis: Evidence for the Secondary Market Theory.

2014-2 Simone Auer: Monetary Policy Shocks and Foreign Investment Income: Evidence from a large Bayesian VAR.
From 2015, this publication series will be renamed SNB Working Papers.

All SNB Working Papers are available for download at: www.snb.ch, Research

Subscriptions or individual issues can be ordered at: Swiss National Bank

Library

P.O. Box

$\mathrm{CH}-8022$ Zurich

Phone: +41446313284

Fax: +41446318114

E-mail: library@snb.ch 
